\title{
Clause of Unlawful Action that May Void Arbitration Rules
}

\author{
Ahmad Yani Kosali ${ }^{*}$, Dimas Pratama Putra ${ }^{2}$ \\ ${ }^{1}$ Public Administration Science, Satya Negara University, Palembang, Indonesia \\ ${ }^{2}$ Economic Department, Tridinanti University, Palembang, Indonesia
}

\begin{abstract}
Arbitration is a way of resolving a civil dispute outside a public court based on an arbitration agreement made in writing by the disputing parties. The problem in this research is whether the Arbitration decision can be overturned by the District Court because it contains clauses of illegal acts?, and What are the forms of illegal acts that can be overturned by the District Court? The type of research used is descriptive normative legal research. From the results of the research, it can be concluded that: An Arbitration Award can be overturned by the District Court because it contains a clause on illegal acts, is a decision that has been tested and examined through a civil court hearing that it is proven based on the evidence submitted by the disputing parties that the arbitration award contains actions against the law. And a form of illegal action that can be annulled by the District Court is a decision that has permanent legal force stating that the arbitration award is proven to have been an illegal act committed by one of the parties.
\end{abstract}

Keywords: Clause, Unlawful Acts, and Arbitration.

*Corresponding Author:

E-mail: yanikosali@gmail.com (Ahmad Yani Kosali)

Administrative Science, Satya Negara University, Palembang, Indonesia

\section{INTRODUCTION}

The advancement of world trade, on the one hand, does have a positive impact, but on the other hand it can lead to differences in understanding, disagreements or disputes or disputes as a result of one party defaulting on the trade contract.

According to (Satjipto Rahardjo, 2001), the law that can provide facilities so that the contract agency can carry out its functions properly is an invaluable aid.

Disagreements, disagreements, disagreements and disputes cannot be allowed to drag on and must be resolved satisfactorily for all parties. One that is quite popular and in great demand today is the method of dispute resolution through arbitration in which an arbitral award only has executive power after obtaining permission or an order to be executed from the court, (Basic Law on Judicial Powers in the elucidation of Article 3 paragraph (1).
According to (Gary Goodpaster, 2002), every community has various ways to obtain agreement in the case process or to resolve disputes and conflicts. The method used in a particular dispute and conflict clearly has consequences, both for the disputing parties and the community in the broadest sense. Because of these consequences, it is very necessary to channel certain disputes to a dispute resolution mechanism that is most appropriate for them.

Arbitration is a way of resolving a civil dispute outside a public court based on an arbitration agreement made in writing by the disputing parties. This arbitration award certainly involves an international arbitration award, because trade involves parties of different nationalities.

The problems in this study are:
Journal Homepage:

http://ejournal.undwi.ac.id/index.php/jsds
Copyright (C) 2021 Dwijendra University. All right reserved. 
Journal of Sustainable Development Science

Vol. 3, No. 1, June 2021, pp. 26-34

e-ISSN: 2715-9140 | p-ISSN: 2722-919X

1. Can an Arbitration Award be overturned by the District Court because it contains a clause on illegal acts?

2. What forms of illegal acts can be overturned by the District Court?

\section{METHODS}

The research method used in this research is a type of normative legal research, which means research that describes, examines, explains and analyzes problems. According to (Jonny Ibrahim, 2006), "Normative legal research is a scientific research procedure to find the truth based on the logic of legal science from its negative side. The scientific logic in normative legal research is built on the basis of scientific disciplines and the workings of normative legal science. "

\subsection{Definition and Terms of Legality of the Agreement}

The theory of legal science put forward by (Setiawan, 2000) states that the law of agreement is classified into the Law of a Person and the Law of Wealth because this is a combination of a person's ability to act and relate to matters regulated in an agreement which can be something which is valued in money.

According to (Salim H. S., 2008), the legal term agreement or contract is a translation from English, namely contractlaw, while in Dutch it is called overeenscomsrecht.

An agreement is an event in which someone promises to another person or where the two people promise each other to do something, (R. Subekti, 2004).

The elements listed in the agreement/contract law can be put forward, according to (Salim H. S., 2008) as follows:

1. There is a rule of law.

2. Legal subjects.

3. There are achievements.
4. Consensus.

5. Legal consequences.

According to (Salim H. S., 2008), an engagement is a legal relationship between two people or two parties, based on which one party has the right to demand something from the other party, and the other party is obliged to fulfill these demands.

"An agreement must be about a certain matter, meaning that an agreement must have a certain object, at least it can be determined. That certain objects can be objects that now exist and will exist later, (Mariam Darus Badrulzaman, 2000). "

\subsection{Principles in the Covenant}

The principles in contract law are as follows:

1. The principle of freedom of contract.

2. The Principle of Consensualism.

3. The Principle of Good Faith

4. Binding Strength Principle

\subsection{Arbitration as an Alternative to Dispute Resolution}

The arbitration process begins with the submission of a warrant by the applicant, Article 38 of Law Number 30 Year (1999) stipulates that within a period determined by the arbitrator or arbitral tribunal, the applicant must submit a letter of demand to the arbitrator or arbitral tribunal. The letter of claim must be submitted in writing and at least contain:

1. Identity of the parties, namely the full name and place of residence or domicile of the parties;

2. A brief description of the dispute or dispute, accompanied by attachments of evidence, such as a copy of the arbitration agreement.

3. Clear content of claim, if the content of the claim is in the form of money, then the exact amount must be stated.
Journal Homepage:

http://ejournal.undwi.ac.id/index.php/jsds
Copyright (C) 2021 Dwijendra University. All right reserved. 
Journal of Sustainable Development Science

Vol. 3, No. 1, June 2021, pp. 26-34

e-ISSN: 2715-9140 | p-ISSN: 2722-919X

Immediately after receiving the demand letter from the applicant, the arbitrator or the chairman of the arbitral tribunal will submit a copy of the claim to the respondent. The said letter of demand is accompanied by an order that the respondent must respond and provide his answer in writing within 14 (fourteen) days from the receipt of a copy of the claim by the respondent. As in the judicial process, at the first trial the arbitrator attempted and proposed that the disputing parties establish peace.

If the respondent answers the applicant's demand letter, the arbitrator will immediately submit a copy of the answer to the applicant. At the same time, the arbitrator orders the parties or their proxies to appear before the arbitral tribunal which is determined no later than 14 (fourteen) days from the issuance of the summons order.

During the main examination of the arbitration dispute, the parties within a certain period determined by the arbitrator are given the opportunity to explain in writing about their respective positions accompanied by submission of evidence deemed necessary to corroborate their position. The arbitrator has the right to ask the parties to submit additional written explanations, documents or other evidence deemed necessary within a period determined by the arbitrator.

After the arbitration or arbitral tribunal has finished examining the arbitration dispute, it will issue an arbitral award to end the arbitration dispute being examined, and the arbitrator can also provide an arbitrary opinion.

Basically, an arbitration award must be implemented voluntarily by the parties, if the parties do not implement it voluntarily, then the arbitration award is enforced by force, that is, by first being deported in the registration deed at the district court. The deadline for submission and registration of the national arbitration award is within 30 (thirty) days from the date the award is pronounced by the arbitrator or arbitral tribunal. If the deponir's actions against the national arbitration award are not fulfilled, it will result in the inability to enforce the national arbitration award.

\subsection{Examination of Civil Cases Before the Trial}

According to (Sudikno

Mertokusumo, 2008), the authority of the District Court is absolute authority or absolute competence that cannot be exercised by other courts, both within the same judicial body and within other judicial bodies.

According to (Sudikno Mertokusumo, 2008), in general it can be said that a District Court has the relative authority to accept, examine and adjudicate and resolve cases where the defendant resides in its jurisdiction.

According to (Riduan Syahrani, 2007), at the time of filing a lawsuit that was submitted at the secretariat of the District Court, the plaintiff had to pay the court fee which included the cost of the clerk's office, the cost of summons and notification to the parties. The amount of the court fee in the first stage is determined by the Head of the District Court as a down payment for the cost of the case. After the investigation of the case has proceeded, if it turns out that the down payment for the cost of the case is insufficient, the plaintiff must pay again until it is sufficient. For those who cannot afford it, they can proceed for free, namely by submitting an application first to the Head of the District Court. In which application is attached a statement of incapacity signed by the Camat of the area
Journal Homepage:

http://ejournal.undwi.ac.id/index.php/jsds
Copyright (C) 2021 Dwijendra University. All right reserved. 
Journal of Sustainable Development Science

Vol. 3, No. 1, June 2021, pp. 26-34

e-ISSN: 2715-9140| p-ISSN: 2722-919X

where the concerned resides. This application for free proceedings or prodeo was answered by the panel of judges at the District Court at the first trial.

After a lawsuit is filed and registered by the clerk in a list for this purpose, the Chairperson of the District Court or the chairperson of the panel of judges who has been appointed to examine the case, determines the day of the trial and orders to summon both parties to be present accompanied by the witnesses they want to be examined and bring all certificates that will be used.

The summoning of the parties in a case is attempted by the bailiff or substitute bailiff to actually meet the person summoned at his residence, if he does not meet the person concerned, the summons must be delivered to the Village Head or Lurah, who is obliged to notify the summons to the concerned.

The possible consequences for the person being sued in a civil case, because they do not receive a summons or notification through the village head or head of the village, will be defeated by a verstek decision. If later the verstek decision is notified by the bailiff, he does not meet as well and the Village Head subsequently neglects to inform him of the decision, then he is very disadvantaged, because of that incident the time limit for submitting a verzet against the verdict passed accidentally, Riduan Syahrani (2007: 37).

\section{RESULT AND DISCUSSION}

3.1. An Arbitration Award can be overturned by the District Court because it contains a clause of illegal acts.

There are two main ways to distinguish the different forms of dispute resolution:

1. Is the process competitive or cooperative (collaboration) and;

2. Whether the third party decides the dispute or the parties negotiate the settlement independently or with the assistance of a third party.

Thus, the position of the arbitration agreement is the main basis for the parties to resolve their dispute through arbitration, because this is the choice of the parties in entering into an agreement or contract.

Due to the various weaknesses inherent in court bodies in resolving disputes, both weaknesses that can be corrected or not, many people want to find other ways or other institutions to resolve disputes outside of court bodies such as arbitration, even though arbitration is not the only way to resolve disputes outside the court for example: through mediation / negotiation, administrative decisionmaking bodies, ombudsman, and internal tribunals.

According to the Arbitration Law Number 30 of 1999, the applicant must submit a letter of demand, followed by an answer and if there is a counterclaim from the respondent. This is followed by summons for hearings and examination of witnesses, expert witnesses and other evidence. After that, the arbitration will give its decision.

Arbitrator is a referee in a dispute resolution. In principle, anyone can be an arbitrator as long as they have the expertise that is expected to resolve the ongoing dispute. An arbitrator can be a legal expert, or an expert in a particular field.

In an arbitration process known as the right of refusal, what is meant by the right of refusal is the right of the disputing parties to reject one or more of the arbitration based on strong evidence, there are reasons that

Journal Homepage:

http://ejournal.undwi.ac.id/index.php/jsds
Copyright $@ 2021$ Dwijendra University. All right reserved. 
Journal of Sustainable Development Science

Vol. 3, No. 1, June 2021, pp. 26-34

e-ISSN: 2715-9140 | p-ISSN: 2722-919X

doubt the objectivity in providing the verdict.

Therefore, the power to bind the arbitration agreement is for the parties who have agreed to make choices on arbitration settlement, so if a dispute occurs, the case cannot go directly to court before it is resolved through the arbitration process.

This is in line with the provisions of Article 3 of Law Number 30 Year 1999 concerning Arbitration and Alternative Dispute Resolution, which stipulates that "District Courts are not authorized to adjudicate disputes between parties that have been bound by an arbitration agreement.

Article 4 of Law Number 30 of 1999 concerning Arbitration and Alternative Dispute Resolution determines as follows:

(1) In the event that the parties have agreed that the dispute between them will be resolved by arbitration and the parties have given authority, the arbitration has the authority to determine in its decision the rights and obligations of the parties if this is not regulated in their agreement.

(2) The agreement to settle a dispute by arbitration as referred to in paragraph (1) shall be contained in a document signed by the parties.

(3) In the event that it is agreed that the dispute settlement by arbitration occurs in the form of an exchange of letters, the sending of telex, telegram, facsimile, e-mail or other forms of communication, must be accompanied by a note of acceptance by the parties.

The District Court is a court that has the duty and authority to examine, decide and settle criminal and civil cases at the first level. The duties and powers of the District Court in civil cases include all cases concerning property rights and rights arising

Journal Homepage:

http://ejournal.undwi.ac.id/index.php/jsds out of it as well as other civil rights, including the resolution of problems related to rights claims that do not contain disputes, unless the law stipulates another court. to examine, decide and settle them, such as the parties who are not satisfied with an arbitration award because it is indicated that it contains illegal acts.

Based on the findings of the researcher that the Arbitration Award can be overturned by the District Court because it contains clauses of illegal acts, it is a decision that has been tested and examined through a civil court hearing that it is proven based on the evidence submitted by the disputing parties that the arbitration award contains illegal acts.

\subsection{Forms of Unlawful Actions That Can Be Canceled by the District Court}

Law Number 30 Year 1999 requires that an arbitration agreement must be made in writing. The written terms of the arbitration agreement can be in the form of an agreement in the form of an arbitration clause which is stated in a written agreement made by the parties before the dispute arises; or a separate arbitration agreement made by the parties after the dispute arises.

The focus of the arbitration agreement is aimed at resolving disputes arising from the agreement. This agreement is not a conditional agreement. The implementation of the arbitration agreement is not dependent on certain events in the future. This agreement does not question the way and the institution which is authorized to resolve disputes that occur between parties.

The arbitration agreement is not attached to an integral part of the subject matter of the agreement. An arbitration agreement that is commonly called an arbitration clause is an addition to the main agreement. So it is an accessory, in which 
Journal of Sustainable Development Science

Vol. 3, No. 1, June 2021, pp. 26-34

e-ISSN: 2715-9140 | p-ISSN: 2722-919X

its existence is only as an addition to the main agreement and in no way affects the fulfillment of the main agreement. Even without an arbitration agreement, the principal agreement can continue and standalone perfectly. On the other hand, without a basic agreement, there will never be an arbitration agreement.

In Law Number 30 of 1999, we recognize two forms of arbitration clauses, namely:

\section{Pactumcompromittendo}

In pactumcompromittendo, the parties binding the agreement will resolve the dispute through an arbitration forum before a real dispute occurs. The form of this pactumcompromittendo clause is regulated in Article 7 of Law Number 30 of 1999 concerning Arbitration and Alternative Dispute Resolution. The article reads:

The parties can agree on a dispute that occurs or will occur between them to be resolved by arbitration.

According to (Abdulkadir Muhammad, 2008), there are two ways of making the pactumcompromittendo clause, namely:

a. By including the arbitration clause concerned in the main agreement. This method is the most common method.

b. The pactumcompromittendo clause is made separately in a separate deed.

2. Deed of Compromise

In Law Number 30 of 1999 the compromise deed is regulated in Article 9 which reads:

(1) In the event that the parties choose to settle the dispute through arbitration after the dispute has occurred, the agreement regarding this matter must be made in a written agreement signed by the parties.

(2) In the event that the parties are unable to sign the written agreement as referred to in paragraph (1), the written agreement must be made in the form of a notarial deed.

(3) The written agreement as meant in paragraph (1) must contain:

a. the problem in dispute;

b. full names and residences of the parties;

c. the full name and residence of the arbitrator or arbitral tribunal;

d. the place where the arbitrator or arbitral tribunal will make a decision;

e. the full name of the secretary;

f. dispute settlement period;

g. arbitrary willingness statement; and

h. a statement of the willingness of the disputing parties to bear all costs necessary for the settlement of the dispute through arbitration.

(4) A written agreement which does not contain the matters referred to in paragraph (3) shall be null and void.

The difference between pactumcompromittendo and deed of compromise lies only at the time of making the agreement. The pactumcompromittendo was created before the dispute occurred. In terms of the agreement between the two there is no difference (Rachmadi Usman, 2006).

The arbitration agreement is a contract. As mentioned above, the agreement can be part of a contract or a separate contract. An arbitration agreement in a contract can be called an arbitration
Journal Homepage:

http://ejournal.undwi.ac.id/index.php/jsds
Copyright (C) 2021 Dwijendra University. All right reserved. 
Journal of Sustainable Development Science

Vol. 3, No. 1, June 2021, pp. 26-34

e-ISSN: 2715-9140 | p-ISSN: 2722-919X

clause. An arbitration clause can be a simple agreement to enforce an arbitration, but it can also be a more comprehensive agreement, containing the terms of the arbitration.

This arbitration clause is important because it will determine the progress of an arbitration, how it will be carried out, what substantive laws apply, and others.

Arbitration clauses must be carefully drafted to prevent litigation procedures about their meaning and to avoid unpleasant surprises at a later date. The arbitration clause must contain a clear commitment to arbitration as well as a statement regarding the type of dispute resolved through this arbitration forum or institution.

According to the Arbitration Law Number 30 of 1999, the applicant must submit a letter of demand, followed by an answer and if there is a counterclaim from the respondent. This is followed by summons for hearings and examination of witnesses, expert witnesses and other evidence. After that, the arbitration will give its decision.

Arbitrator is a referee in a dispute resolution. In principle, anyone can be an arbitrator as long as they have the expertise that is expected to resolve the ongoing dispute. An arbitrator can be a legal expert, or an expert in a particular field.

Article 12 of Law Number 30 Year 1999 concerning Arbitration, determines the requirements of an arbitrator, namely:

1. Proficient in taking legal actions;

2. At least 35 (thirty five) years old;

3. Does not have a blood family relationship or similar to the second degree with one of the parties concerned;

4. Has no other interest in the arbitration award;
5. Having experience and mastering actively in the field for at least 15 years; 6. Judges, prosecutors, clerks and other judicial officials may not be arbitrary.

According to (Gunawan Widjaya, 2005), in determining how many people should be arbitrary in one case, whether three people or just one person, the following factors can be considered, namely:

1. The amount disputed;

2. Complexity of claims;

3. Nationality of the parties;

4. The relevant trade customs or the business or profession involved in the dispute;

5. Availability arbitrarily is feasible;

6. The level of urgency of the case in question.

In an arbitration process known as the right of refusal, what is meant by the right of refusal is the right of the disputing parties to reject one or more of the arbitration based on strong evidence, there are reasons that doubt the objectivity in providing the verdict.

If the arbitrator has already taken his decision, the execution of the national arbitration award will be carried out in two ways, namely:

The implementation of voluntary national arbitration awards is the implementation of decisions that do not require interference from the chairman of the District Court. Meanwhile, if the party who is obliged to carry out its obligations based on the content of the arbitration award does not want to carry out its obligations, the enforcer means that it is necessary to intervene by the head of the District Court and its apparatus to force the execution of the execution concerned. In order for the arbitration award to be executed, an action
Journal Homepage:

http://ejournal.undwi.ac.id/index.php/jsds
Copyright (C) 2021 Dwijendra University. All right reserved. 
Journal of Sustainable Development Science

Vol. 3, No. 1, June 2021, pp. 26-34

e-ISSN: 2715-9140 | p-ISSN: 2722-919X

called the Registration Deed must be carried out.

After the arbitration or arbitration panel has finished examining the arbitration dispute, it will issue an arbitration award to end the arbitration dispute being examined. Besides giving an arbitration award, the arbitrator or arbitral tribunal can also provide a binding opinion on a matter relating to the agreement. Thus, there are two kinds of products made by arbitrators or arbitral tribunals, namely decisions and arbitration opinions.

An arbitration award is an award given by an adhoc arbitration institution or an arbitration institution for a difference of opinion, dispute of understanding or dispute regarding a matter of issue arising from a basic agreement (which contains an arbitration clause) submitted to an adhoc arbitration or arbitration institution for its decision.

In the absence of a dispute, the arbitration institution may accept requests submitted by the parties to an agreement, to provide a binding opinion regarding a certain legal relationship of an agreement in the event that a dispute has not yet arisen. The arrangement can be found in Article 52 of Law Number 30 Year 1999. This article stipulates that the parties to an agreement have the right to request a binding opinion from the arbitration institution on the particular legal relationship of an agreement. For example regarding the interpretation of ambiguous provisions in an agreement, additions or changes to provisions relating to the emergence of new conditions.

By giving an opinion by the arbitration institution, both parties are bound by it as in an agreement (contract). If any of the parties acts contrary to the opinion given by the arbitrator or the arbitral tribunal, then the party concerned is deemed to have violated the agreement or default (broken promise).

In essence, an award or an arbitration opinion contains a statement uttered by the arbitrator or arbitral tribunal in writing. The arbitral statement or arbitral tribunal will be in the form of an arbitral award if there is an element of dispute in it, whereas if the arbitral statement or arbitral tribunal is set forth in the form of an arbitration opinion if the content does not contain elements of a dispute. In other words, in an arbitration award there is a dispute between the parties regarding an agreement (contract), otherwise in the arbitration opinion there is no such dispute.

The arbitration agreement is a contract. As mentioned above, the agreement can be part of a contract or a separate contract. An arbitration agreement in a contract can be called an arbitration clause. An arbitration clause can be a simple agreement to enforce an arbitration, but it can also be a more comprehensive agreement, containing the terms of the arbitration.

A form of illegal action that can be overturned by the District Court, namely a decision that has permanent legal force stating that the arbitration award is proven to have been an illegal act committed by one of the parties.

\section{CONCLUSIONS}

Based on the results of the study, the researchers concluded that:

1. An Arbitration Award can be overturned by the District Court because it contains a clause on illegal acts, is a decision that has been tested and examined through a civil court hearing that it is proven based on evidence submitted by the disputing
Journal Homepage:

http://ejournal.undwi.ac.id/index.php/jsds
Copyright (C 2021 Dwijendra University. All right reserved. 
Journal of Sustainable Development Science

Vol. 3, No. 1, June 2021, pp. 26-34

e-ISSN: 2715-9140 | p-ISSN: 2722-919X

parties that the arbitration award

contains illegal acts.

2. A form of unlawful act that can be annulled by the District Court, namely a decision that has permanent legal force which states that the arbitration award is proven to have been an illegal act committed by one of the parties.

\section{REFFERENCES}

Abdulkadir Muhammad. (2008). Indonesian Company Law. Citra Aditya Bakti.

Gary Goodpaster. (2002). A Review of Arbitration Dispute Resolution in Indonesia. Citra Aditya Bakti.

Gunawan Widjaya. (2005). Alternative Dispute Resolution. Rajawali Grafindo Persada.

Jonny Ibrahim. (2006). Legal Research. Prenada Media Group.

Mariam Darus Badrulzaman. (2000). The Civil Code Book II of the Bond Law with Explanations. Alumni.

R. Subekti. (2004). Agreement Law. Intermasa. Rachmadi Usman. (2006). National Arbitration Law. Gramedia Widiasarana Indonesia.

Law Number 30 of 1999 concerning Alternative Dispute Resolution and Arbitration, (1999).

Riduan Syahrani. (2007). Civil Procedure Law District Court. Main Library.

Salim H. S. (2008). Contract Law: Contract Formulation Theory \& Techniques. Sinar Grafika.

Satjipto Rahardjo. (2001). Law and Society. Space.

Setiawan. (2000). Engagement Law. Alumni.

Sudikno Mertokusumo. (2008). Indonesian Civil Procedure Law. Liberty. 